\title{
Frequencies of X-ray induced chromosome aberrations in lymphocytes of xeroderma pigmentosum and Fanconi anemia patients estimated by Giemsa and fluorescence in situ hybridization staining techniques
}

\author{
Radha Saraswathy and A.T. Natarajan
}

\begin{abstract}
Blood lymphocytes from xeroderma pigmentosum (XP) and Fanconi anemia (FA) patients were assessed for their sensitivity to ionizing radiation by estimating the frequency of $\mathrm{X}$-ray ( 1 and $2 \mathrm{~Gy}$ )-induced chromosome aberrations $(\mathrm{CA})$. The frequencies of aberrations in the whole genome were estimated in Giemsa-stained preparations of lymphocytes irradiated at $\mathrm{G}_{0}$ or $\mathrm{G}_{2}$ stages. The frequencies of translocations and dicentrics involving chromosomes 1 and 3 as well as the X-chromosome were determined in slides stained by fluorescence in situ hybridization (FISH) technique. An increase in all types of CA was observed in XP and FA lymphocytes irradiated at $\mathrm{G}_{0}$ when compared to controls. The frequency of dicentrics and rings was 6 to $27 \%$ higher (at 1 and $2 \mathrm{~Gy}$ ) in XP lymphocytes and $37 \%$ higher (at 2 Gy) in FA lymphocytes than in controls, while chromosome deletions were higher in irradiated (30\% in $1 \mathrm{~Gy}$ and $72 \%$ in $2 \mathrm{~Gy}$ ) than in control XP lymphocytes and 28 to $102 \%$ higher in FA lymphocytes. In $\mathrm{G}_{2}$-irradiated lymphocytes the frequency of CA was 24 to $55 \%$ higher in XP lymphocytes than in controls. In most cases the translocation frequencies were higher than the frequencies of dicentrics (21/19).
\end{abstract}

\section{INTRODUCTION}

Ionizing radiation induces chromosome aberrations in $\mathrm{G}_{0}$ human peripheral lymphocytes which can be classified as unstable (dicentrics, centric rings and acentric fragments) or stable (various kinds of translocations) (Natarajan et al., 1992, 1994). Unstable aberrations are lost during successive cell divisions whereas the stable ones can persist for a long time (Natarajan et al., 1991; Lucas et al., 1992; Boei et al., 1994). The frequencies of structurally aberrant chromosomes in peripheral lymphocytes of persons accidentally exposed to ionizing radiation have been used since the 1960s to estimate absorbed radiation dose (Bender and Gooch, 1966; Sasaki and Miyata, 1968; Natarajan, 1984).

According to classical models of formation of chromosome exchange aberrations, the ratio of radiation-induced symmetrical exchanges (reciprocal translocations, inversions) and asymmetrical exchanges (dicentrics, rings) should be 1:1 (Evans, 1962). A change in this ratio in favor of translocation frequencies has been observed (Natarajan et al., 1992; Schmid et al., 1992; Nakano et al., 1993), and it has been suggested that the higher estimate of translocations in these studies may be due to the misclassification of exchange aberrations. This problem could be overcome by combination of whole chromosome marking with centromere specific DNA probes (Weier et al., 1991). Straume and Lucas (1993) found a close correlation between dicentrics and reciprocal translocations even after the application of these techniques. Finnon et al. (1995) also observed that the yield of radiation-induced translocations was not significantly higher than that of dicentrics. Natarajan et al. (1996) explained this by suggesting that if one confines scoring only to reciprocal translocations, ignoring other types such as terminal and interstitial translocations, then the frequencies of dicentrics and translocations are almost equal. In general, the frequency of translocations has been found to be higher than the frequency of dicentrics. This shift may be dependent upon the structure of the chromosomes, position of the centromere (Natarajan et al., 1996), and the nature of the chromatin at the time of irradiation (Vyas et al., 1991). The formation of these two types of aberrations (translocations and dicentrics) may be the result of different mechanisms (Natarajan et al., 1996).

Fanconi anemia (FA) and xeroderma pigmentosum (XP) are rare repair-deficient, mutagen-sensitive, autosomal recessive human disorders with chromosome instability, which are cancer prone. Cells derived from FA patients have more spontaneous chromosomal damage than those of other instability syndromes (Schroeder et al., 1964, 1989; Natarajan et al., 1989). There exist inter- and intraindividual variations specifically with regard to susceptibility to cross-linking agents and X-rays (Sasaki and Tonomura, 1973).

$\mathrm{XP}$ is characterized by high sensitivity to sun exposure, susceptibility to skin cancer, cutaneous pigmentation, impaired DNA repair and, in some patients, neurological degeneration (Kraemer and Slor, 1985). These patients have a greater than 1000-fold-increased frequency of UV-induced skin cancer (Cleaver and Kraemer, 1989) when compared with the normal population. 
Several studies (Bigelow et al., 1979; Arlett and Harcourt, 1980; Parshad et al., 1983) have shown increased radiosensitivity of XP and FA cells in the $\mathrm{G}_{2}$ phase of the cell cycle, but in other studies an increase in chromosomal aberrations was not observed in FA cells (Evans et al., 1978; Sasaki, 1978) and XP fibroblasts (Darroudi et al., 1995).

The present study was designed to estimate the frequencies of X-ray-induced chromosome aberrations in lymphocytes of XP and FA patients.

\section{MATERIAL AND METHODS}

\section{Culture conditions}

Venous blood drawn in lithium heparin tubes was set up for whole blood cultures in Ham's F10 medium supplemented with $15 \%$ heat inactivated fetal calf serum (Gibco), phytohemagglutinin and antibiotics. The cultures were incubated at $37^{\circ} \mathrm{C}$ in a $5 \% \mathrm{CO}_{2}$ atmosphere. The FA blood sample was obtained from the Academic Hospital, Leiden, and XP from the Institute of Human Genetics, Budapest, Hungary; the complementation groups of these patients are not known.

$\mathrm{X}$-Rays were generated by an ENRAF machine, operating at $200 \mathrm{kV}, 6 \mathrm{~mA}$ at a dose rate of $2 \mathrm{~Gy} / \mathrm{min}$.

\section{Treatment}

\section{$G_{0}$ irradiation}

Normal, XP and FA blood lymphocyte cultures were irradiated with a dose of 1 or $2 \mathrm{~Gy}$ and harvested $48 \mathrm{~h}$ after initiation of the cultures. Colcemid (Sigma; $0.3 \mu \mathrm{g} / \mathrm{ml}$ ) was added to the cultures 2-3 h before harvest. 5-Bromo-2deoxyuridine (BrdU, Sigma; $10 \mu \mathrm{M}$ ) was added to all the cultures after irradiation for identification of first and second division cells. Scoring of chromosomal aberrations was restricted to cells at first mitosis.

\section{$G_{2}$ irradiation}

Lymphocyte cultures were set up and grown for $69 \mathrm{~h}$ and then irradiated with doses of 0.5 or $1 \mathrm{~Gy}$. Colcemid was added to these cultures $0.5 \mathrm{~h}$ after irradiation and the lymphocytes were harvested and fixed after $2.5 \mathrm{~h}$. For harvesting the cultures, cells were subjected to hypotonic shock $(0.075 \mathrm{mM} \mathrm{KCl})$ for $25 \mathrm{~min}$ and fixed in acetic acid:methanol (1:3). Appropriate controls were prepared.

For $\mathrm{G}_{0}$ irradiation studies, air-dried preparations were stained by the fluorescence plus Giemsa (FPG) technique (Perry and Wolff, 1974). Two hundred metaphases were analyzed for the presence of dicentrics, rings and chromosome fragments for each radiation dose. For $\mathrm{G}_{2}$ irradiation studies, the slides were stained with 5\% Giemsa solution. Chromatid gaps, chromatid breaks, isochromatid breaks and chromatid exchanges were scored in 200 cells at each dose.
Fluorescence in situ hybridization

Slides to be processed for in situ hybridization were stored dry at $-20^{\circ} \mathrm{C}$. Chromosome specific libraries were obtained from blue-scribe plasmids. A mixture of three different chromosomes (1, 3 and $\mathrm{X}$ ) was used. The in situ hybridization method routinely used in our laboratory (Natarajan et al., 1992) was adapted. In order to analyze the aberrations in the first mitosis, the slides were stained with Hoechst 33258 (Sigma), exposed to UV light and processed for in situ hybridization (Boei et al., 1994).

Triple-color hybridization was performed using biotin 11-dUTP (chromosome number 1; Sigma), digoxigenin 11-dUTP (chromosome number 3; Boehringer Manheim, Germany) and fluorescein 12-dUTP (X-chromosome; Boehringer). The labelled DNA representing the library was combined with competitive (human cot 1 DNA) DNA followed by denaturation, then hybridized in situ (overnight at $37^{\circ} \mathrm{C}$ ) with metaphase preparation.

For immunological detection, after hybridization the slides were washed successively in $50 \%$ formamide $/ 2 \mathrm{X}$ $\operatorname{SSC}\left(42^{\circ} \mathrm{C}\right), 0.1 \mathrm{X} \mathrm{SSC}\left(60^{\circ} \mathrm{C}\right)$ and $4 \mathrm{X} \mathrm{SSC} / 0.05 \%$ Tween $20, \mathrm{pH} 7$, at room temperature. The first incubation was carried out with immunological buffer (NFDM) for 30 min at room temperature. After four washes with SSC, $0.05 \%$ Tween 20 and TNT $(0.1 \mathrm{M}$ Tris-HCl, $0.15 \mathrm{M} \mathrm{NaCl}$ and $0.05 \%$ Tween 20 ), the second incubation with antibodies avidin-FITC and mouse anti-digoxigenin diluted in TNB $(0.1 \mathrm{M}$ Tris- $\mathrm{HCl}, 0.15 \mathrm{M} \mathrm{NaCl}$ and $0.5 \%$ Boehringer blocking agent) was performed at $37^{\circ} \mathrm{C}$ for $30 \mathrm{~min}$. The third incubation was carried out with goat-anti-avidin D and sheep anti-mouse dig diluted in TNB for $30 \mathrm{~min}$ at $37^{\circ} \mathrm{C}$. The fourth incubation was carried out with avidinFITC and sheep anti-dig TRITC for $30 \mathrm{~min}$ at $37^{\circ} \mathrm{C}$. Each incubation was followed by washing with TNT. After the final wash with PBS the slides were counter-stained with DAPI (4,6-diamidino-2-phenylindole; Sigma) diluted in an anti-fading agent, vectashield (Vector Laboratories) (Figure 1).

In order to detect translocations, dicentrics and complex exchanges involving chromosome numbers 1 and 3 and the X-chromosome, 300 to 500 metaphases were analyzed for each radiation dose using a Zeiss fluorescence microscope equipped with triple filters. Due to variations in mitotic index the number of metaphases scored by FISH varied for each experimental point. The translocations and dicentrics were scored using the same slide. The background frequencies were subtracted to obtain the induced frequency of translocations and dicentrics.

The genomic translocation and dicentric frequencies were calculated using the formula for correction of the probed fraction of the genome (Lucas et al., 1992). This formula relates the translocation frequency measured by FISH, Fp, to the genomic translocation frequencies, $F_{G}$, through the fraction of the genome covered by the probes, $\mathrm{fp}$, as follows: 


$$
F_{G}=\frac{F_{p}}{2.5 \times f p(1-f p)}
$$

\section{RESULTS AND DISCUSSION}

\section{Spontaneous chromosomal aberrations in normal, XP and FA lymphocytes}

The baseline aberration frequencies in normal and XP lymphocytes were in the range of 2 to $3 \%$, whereas in FA the frequency was 23\% (Table I). Darroudi et al. (1995) also observed a similar spontaneous aberration frequency in the range of 2 to $3 \%$ in the normal and XP-C cell lines, and 16 to $22 \%$ in FA cells, which is known to be characteristic of FA patients (Schroeder et al., 1964; Natarajan et $a l ., 1989)$. However, the frequency of spontaneous aberrations in XP lymphocytes was similar to that of normal lymphocytes.

\section{$\mathrm{G}_{0}$ radiation induced $\mathrm{CA}$ in normal, XP and FA lymphocytes}

To compare the aberration frequencies in XP, FA and normal lymphocytes the background aberration frequencies were subtracted from the induced aberration frequencies. The frequency of dicentrics and rings in XP and in FA lymphocytes was markedly high. There was a high frequency of chromosome deletions with a 30-72\% increase in XP lymphocytes after 1 and 2 Gy of X-rays and a 28-102\% increase in deletions in the FA lymphocytes as compared with normal lymphocytes. The ratio between the frequencies of dicentrics and chromosome deletions was 1:0.6 and 1:0.8 in normal lymphocytes, $1: 1.9$ and $1: 1.6$ in XP lymphocytes and 1:3.8 and 1:1.8 in FA lymphocytes (1 and 2 Gy, respectively). The frequencies of chromatid type aberrations in FA lymphocytes were more than 30 times higher when compared with XP lymphocytes and no chromatid aberration was observed in normal lymphocytes, while chro-
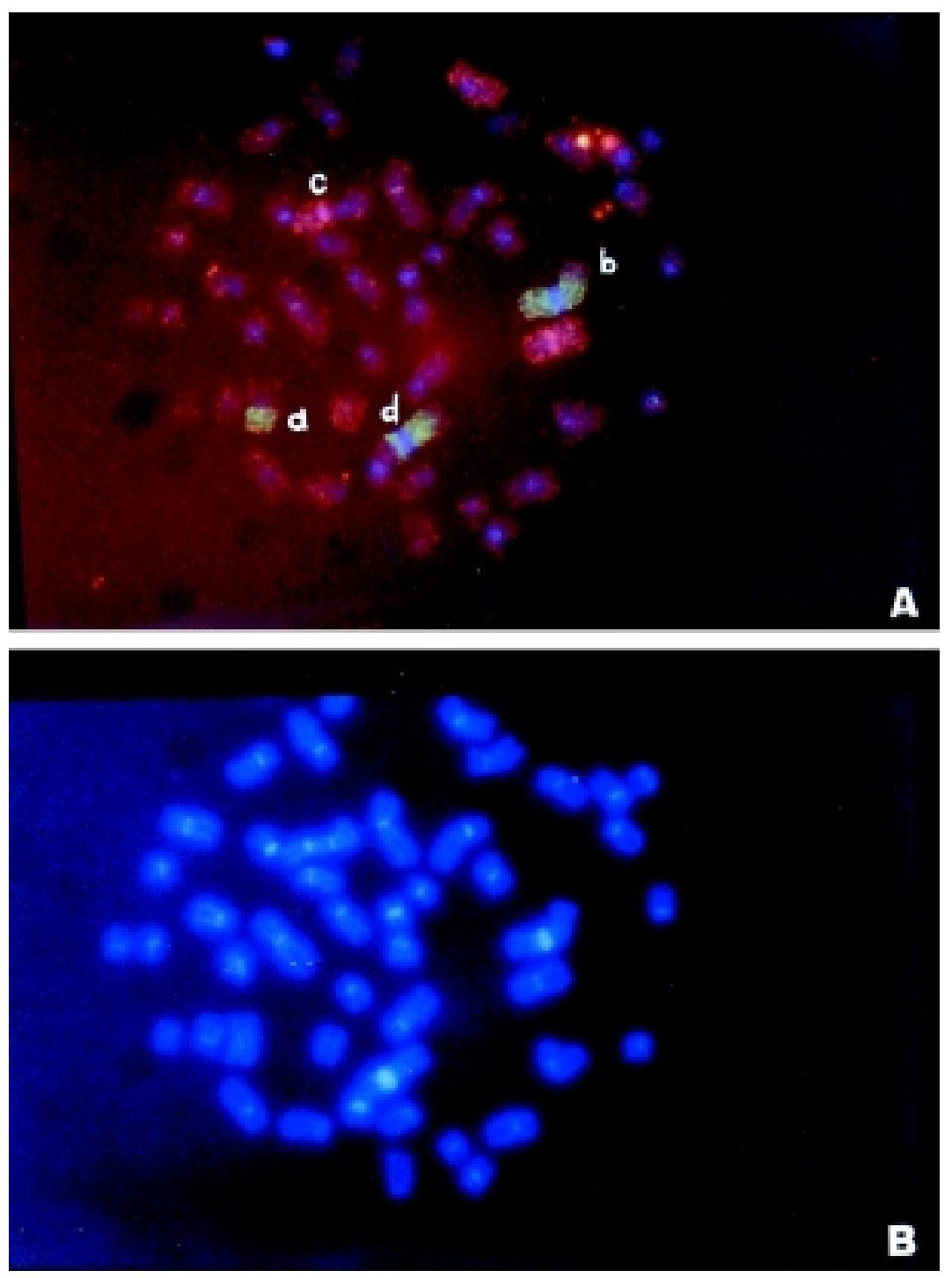

Figure 1 - A. Metaphase spread of an irradiated lymphocyte painted with libraries for chromosomes 1,3 and $\mathrm{X}$ showing translocations (a, b) involving chromosome 1 and dicentrics involving chromosome 3 (c) and chromosome $1(\mathbf{d})$. B. The same cell counter-stained with DAPI (4,6-diamidino-2-phenylindole). 
matid exchanges were only observed in FA lymphocytes, a known characteristic of these cells. $\mathrm{G}_{0}$ radiation produced chromatid breaks/gaps in FA lymphocytes ( 0.37 and 0.36 per cell in 1 Gy and 2 Gy, respectively) and were zero in normal lymphocytes and 0.01 in XP lymphocytes, which further confirms a positive defect in repair of radiation damage in FA cells.

\section{$\mathrm{G}_{2}$ radiosensitivity in normal and XP lymphocytes}

The frequency of X-ray-induced total CA aberrations in XP lymphocytes was 0.79 and 2.17 per cell for 0.5 Gy and $1 \mathrm{~Gy}$, respectively, while in the normal lymphocytes it was 0.55 and 1.62, indicating an increase (24-55\%) in XP lymphocytes (Table II). The frequency of chromatid and isochromatid breaks in XP lymphocytes was 0.72 and 2.03 for 0.5 and $1 \mathrm{~Gy}$, respectively, while in normal lympho-

Table I - $\mathrm{G}_{0}$ radiosensitivity of human peripheral lymphocytes in normal, xeroderma pigmentosum (XP) and Fanconi anemia

(FA) individuals estimated by Giemsa staining*.

\begin{tabular}{|lcccc|}
\hline X-ray dose & \multicolumn{4}{c|}{ Chromosome aberrations per cell $(\mathrm{n}=200)$} \\
\cline { 2 - 5 } & $\begin{array}{l}\text { Chromatid } \\
\text { break/gap }\end{array}$ & Interchange & $\begin{array}{c}\text { Dicentric } \\
+ \text { ring }\end{array}$ & $\begin{array}{c}\text { Chromosome } \\
\text { deletion }\end{array}$ \\
\hline Normal $(46, \mathrm{XX})$ & & & & \\
Control & - & - & - & 0.02 \\
1 & - & - & 0.15 & 0.10 \\
2 & - & - & 0.31 & 0.25 \\
XP(46,XX) & - & - & 0 & 0.03 \\
Control & - & - & 0.15 & 0.15 \\
0.5 & 0.01 & - & 0.21 & 0.40 \\
1 & 0.01 & - & 0.58 & 0.97 \\
2 & - & - & & \\
FA $(46, \mathrm{XY})$ & & & 0.07 & 0.23 \\
Control & 0.16 & 0.06 & 0.07 & 0.38 \\
1 & 0.37 & 0.04 & 0.68 & 1.27 \\
2 & 0.36 & 0 & 0.68 \\
\hline
\end{tabular}

*Induced aberrations have been corrected for spontaneous aberrations.

Table II - $\mathrm{G}_{2}$ radiosensitivity of human peripheral lymphocytes in normal and xeroderma pigmentosum (XP) individuals estimated by Giemsa staining*.

\begin{tabular}{|lccc|}
\hline X-ray dose (Gy) & \multicolumn{3}{c|}{ Aberrations per cell $(\mathrm{n}=200)$} \\
\cline { 2 - 4 } & $\begin{array}{c}\text { Chromatid } \\
\text { break/gap }\end{array}$ & Interchange & $\begin{array}{c}\text { Isochromatid } \\
\text { break }\end{array}$ \\
\hline Normal $(46, \mathrm{XX})$ & & - & \\
Control & - & 0.01 & - \\
0.5 & 0.54 & 0.02 & - \\
1 & 1.6 & 0 & - \\
XP $(46, \mathrm{XX})$ & & 0.07 & 0.02 \\
Control & 0 & 0.14 & 0.15 \\
0.5 & 0.57 & 1.81 & 0.22 \\
1 & 1.51 & \\
\hline
\end{tabular}

*Induced aberrations have been corrected for spontaneous aberrations. cytes the frequencies were 0.54 and 1.6 , indicating an increase (18-43\%) in the XP lymphocytes when compared to normal lymphocytes. The frequency of interchanges was seven times (6\% at $0.5 \mathrm{~Gy}$ and $12 \%$ at $1 \mathrm{~Gy}$ ) higher in the $\mathrm{XP}$ lymphocytes than in the controls. Isochromatid breaks induced by X-rays were observed only in XP lymphocytes and were dose related $(0.15$ and 0.22 per cell for 0.5 and 1 Gy, respectively). Even though Taylor (1978) observed an increase in chromatid aberrations in XP cells irradiated in $\mathrm{G}_{2}$, it was not as significant as it was in the case of ataxia telangiectasia cells. In XP-C lymphocytes an increase in ionizing radiation-induced chromosome aberrations has been observed in the $\mathrm{G}_{2}$ phase of the cell cycle (Parshad et al., 1983).

\section{Estimation of radiation-induced dicentrics and translocations in normal, XP and FA lymphocytes using FISH}

\section{A. Genomic translocation frequency}

The genomic translocation frequency (including reciprocal and terminal ones) calculated for individual chromosomes $(1,3, \mathrm{X})$ represents about $20 \%$ of the total genome. The translocation frequencies for chromosomes 1 , 3 and the $\mathrm{X}$-chromosome followed the order expected on the basis of their DNA contents in normal lymphocytes. The DNA contents of chromosomes 1, 3 and the X-chromosome are $8.15,6.63$ and $5.08 \%$ of the total genomic value, respectively (Mendelsohn et al., 1973). The translocation frequencies in individual chromosomes of XP lymphocytes when compared with those of the chromosomes of normal lymphocytes showed an increase of $73.2 \%$ in the X-chromosome ( $2 \mathrm{~Gy}$ ) and $48.5 \%$ in chromosome 3 (at 2 Gy). At 1 Gy the translocation frequency was 3.2\% and $10.3 \%$ higher than those of XP lymphocytes for chromosome 3 and the X-chromosome respectively (Table III). In FA lymphocytes, the translocation frequencies for chromosomes 1, 3 and the $\mathrm{X}$-chromosome followed the order based on their DNA content. The translocation frequencies in individual chromosomes of FA lymphocytes were almost equal to the respective chromosomes in normal lymphocytes except for the X-chromosome (27.5\% higher at $1 \mathrm{~Gy}$ ).

\section{Mean translocation frequency of the mixture of chromosomes 1 and 3 and the X-chromosome in normal, XP and FA lymphocytes}

At $1 \mathrm{~Gy}$ the mean translocation frequency in XP lymphocytes was similar to that of normal lymphocytes, while at a dose of $2 \mathrm{~Gy}$ the mean frequency was about twice that of normal lymphocytes. At $1 \mathrm{~Gy}$ the mean frequency of translocation in FA lymphocytes was lower than that of normal but at $2 \mathrm{~Gy}$ it was almost similar to normal (Table IV). 


\section{B. Genomic dicentric frequency}

The genomic dicentric frequencies calculated using the same formula for calculating genomic translocation frequencies, for chromosomes 1, 3 and the $\mathrm{X}$-chromosome in normal and XP lymphocytes at $2 \mathrm{~Gy}$ followed the order based on their DNA contents (Table III). The dicentric frequencies in individual chromosomes of XP lymphocytes when compared with the chromosomes from normal lymphocytes showed an increase of $15.1 \%$ for chromosome 1 (2 Gy) and almost equal for chromosomes 3 and X. In FA lymphocytes, the dicentric frequencies for individual chromosomes (1, 3 and $\mathrm{X})$ followed the order based on their DNA contents.

\section{Ratio between translocation and dicentric frequencies}

The frequency of translocations in control, XP and FA lymphocytes increased 8.4, 10.8 and $10.6 \%$ at $1 \mathrm{~Gy}$ and $3.8,53.9$ and $25.9 \%$ at $2 \mathrm{~Gy}$, respectively, over dicentrics
(Table V). This confirms the observation of Natarajan et al. (1996) that the frequency of translocation is higher than the frequency of dicentrics, indicating that two different mechanisms may be involved in the production of translocations and dicentrics as observed in normal humans.

\section{Complex exchanges and centric rings}

In XP and FA lymphocytes a dose-dependent increase in the frequency of complex exchanges and centric rings was observed, ranging from $0.2-3.3 \%$. These values were not used in our analysis.

\section{CONCLUSIONS}

The frequency of CA produced by $\mathrm{G}_{0}$ and $\mathrm{G}_{2}$ irradiation in XP and FA lymphocytes was higher than that of normal lymphocytes. The deletion type of chromosomal aberrations observed in XP and FA lymphocytes was several fold more abundant than in the normal lymphocytes, reflecting a possible defect in their capacity to repair dam-

Table III - Genomic frequency of translocation and dicentrics in normal, xeroderma pigmentosum (XP) and Fanconi anemia (FA) lymphocytes following X-irradiation as estimated by FISH.

\begin{tabular}{|c|c|c|c|c|c|c|c|c|c|c|c|c|c|}
\hline \multirow{2}{*}{$\begin{array}{c}\text { Chromosome } \\
\text { number }\end{array}$} & \multirow{2}{*}{$\begin{array}{c}\text { X-ray } \\
\text { dose (Gy) }\end{array}$} & \multicolumn{4}{|c|}{ Normal } & \multicolumn{4}{|c|}{$\mathrm{XP}$} & \multicolumn{4}{|c|}{ FA } \\
\hline & & No. of cells & $\mathrm{TT}$ & RT & Dic & No. of cells & TT & $\mathrm{RT}$ & Dic & No. of cells & TT & RT & Dic \\
\hline 1 & 0.5 & 300 & - & - & - & 290 & 11.4 & 1.9 & 4.6 & & - & - & - \\
\hline 1 & 1.0 & 300 & 33.4 & 6.6 & 26.5 & 500 & 34.5 & 4.8 & 12.6 & 583 & 23.9 & 9.1 & 5.2 \\
\hline 1 & 2.0 & 300 & 72.9 & 19.9 & 66.3 & 159 & 112.5 & 35.5 & 81.4 & 483 & 74.1 & 35.2 & 29.3 \\
\hline 3 & 0.5 & 300 & - & - & - & 290 & 2.7 & 0.0 & 2.7 & & - & - & - \\
\hline 3 & 1.0 & 300 & 16.1 & 0.0 & 8.1 & 500 & 12.9 & 4.8 & 17.7 & 583 & 11.0 & 6.9 & 1.9 \\
\hline 3 & 2.0 & 300 & 53.0 & 16.1 & 48.4 & 159 & 101.5 & 35.5 & 45.6 & 483 & 33.4 & 15.0 & 19.5 \\
\hline$X$ & 0.5 & 300 & - & - & - & 290 & 7.1 & 3.5 & 4.0 & & - & - & - \\
\hline$X$ & 1.0 & 300 & 30.9 & 8.1 & 20.6 & 500 & 20.6 & 12.4 & 5.2 & 583 & 3.4 & 3.4 & 0.0 \\
\hline$X$ & 2.0 & 300 & 30.9 & 8.1 & 30.9 & 159 & 104.1 & 51.8 & 29.3 & 483 & 37.2 & 12.4 & 20.0 \\
\hline
\end{tabular}

TT - Total translocation, RT - Reciprocal translocation, Dic - Dicentric.

Table IV - Mean genomic translocation and dicentric frequencies detected using a mixture of chromosomes 1 and 3 and the X-chromosome in normal, xeroderma pigmentosum (XP) and Fanconi anemia (FA) lymphocytes as estimated by FISH.

\begin{tabular}{|c|c|c|c|c|c|c|}
\hline \multirow{2}{*}{$\begin{array}{l}\text { X-ray dose } \\
\text { (Gy) }\end{array}$} & \multicolumn{2}{|c|}{ Normal } & \multicolumn{2}{|c|}{$\mathrm{XP}$} & \multicolumn{2}{|c|}{ FA } \\
\hline & Translocation & Dicentric & Translocation & Dicentric & Translocation & Dicentric \\
\hline 0.5 & - & - & 7.1 & 17.6 & - & - \\
\hline 1.0 & 26.8 & 18.4 & 22.6 & 11.8 & 12.8 & 2.2 \\
\hline 2.0 & 52.3 & 48.5 & 106.0 & 52.1 & 48.2 & 22.3 \\
\hline
\end{tabular}


Table V - Ratio between genomic translocation and dicentric frequencies in normal, xeroderma pigmentosum (XP) and Fanconi anemia (FA) lymphocytes following X-irradiation as estimated by FISH.

\begin{tabular}{|c|c|c|c|c|c|c|c|c|c|}
\hline \multirow{2}{*}{$\begin{array}{l}\text { X-ray dose } \\
\text { (Gy) }\end{array}$} & \multicolumn{3}{|c|}{ Normal } & \multicolumn{3}{|c|}{ XP } & \multicolumn{3}{|c|}{ FA } \\
\hline & $\begin{array}{l}\text { Chrom } \\
\text { No. } 1\end{array}$ & $\begin{array}{l}\text { Chrom } \\
\text { No. } 3\end{array}$ & $\begin{array}{l}\text { Chrom } \\
\text { No. X }\end{array}$ & $\begin{array}{c}\text { Chrom } \\
\text { No. } 1\end{array}$ & $\begin{array}{c}\text { Chrom } \\
\text { No. } 3\end{array}$ & $\begin{array}{l}\text { Chrom } \\
\text { No. X }\end{array}$ & $\begin{array}{c}\text { Chrom } \\
\text { No. } 1\end{array}$ & $\begin{array}{c}\text { Chrom } \\
\text { No. } 3\end{array}$ & $\begin{array}{l}\text { Chrom } \\
\text { No. X }\end{array}$ \\
\hline 0.5 & - & - & - & 2.5 & 1.0 & 1.8 & - & - & - \\
\hline 1.0 & 1.26 & 1.99 & 1.5 & 2.7 & 0.7 & 3.9 & 5.2 & 5.8 & 3.4 \\
\hline 2.0 & 1.1 & 1.1 & 0.7 & 1.4 & 2.2 & 3.6 & 2.7 & 1.7 & 1.9 \\
\hline
\end{tabular}

Chrom No. - Chromosome number.

aged DNA, while the frequency of translocations was higher than the frequency of dicentrics in normal, XP and FA lymphocytes, indicating that more unrepaired breaks were available for interaction in these syndromes in comparison to normal cells. Though XP cells are known to be defective in repairing bulky DNA lesions, increased sensitivity to ionizing radiation has been observed, which may indicate that ionizing radiation induces several classes of DNA lesions and/or XP cells are defective not only in nucleotide excision repair but also in some other minor repair pathways. Similarly, though FA cells are known to be sensitive to cross linking agents, implying a defect in the repair of cross links, they are also known to be sensitive to several classes of clastogenic agents (Sasaki and Tonomura, 1973).

\section{ACKNOWLEDGMENTS}

We would like to thank Dr. K.M. Marimuthu, Prof. Emeritus, Dept. of Genetics, Madras University, India, for his help in the preparation of this manuscript. The research was financially supported by an EU Nuclear Safety Programme grant to ATN.

\section{RESUMO}

Linfócitos sanguíneos de pacientes com xeroderma pigmentosum (XP) e anemia de Fanconi (FA) foram avaliados quanto à sensibilidade à ionização radiante estimando-se a frequiência de aberrações cromossômicas (CA) induzidas por raios-X (1 e 2 Gy). As freqüências de aberrações no genoma inteiro foram estimadas em preparações de linfócitos irradiados nas fases $\mathrm{G}_{0} \mathrm{e}$ $\mathrm{G}_{2}$ coradas com Giemsa. As freqüências de translocações e dicêntricos envolvendo os cromossomos 1 e 3 e o cromossomo $\mathrm{X}$ foram determinadas em lâminas coradas por hibridização fluorescente in situ (FISH). Um aumento em todos os tipos de CA foi observado em linfócitos XP e FA irradiados na fase $\mathrm{G}_{0}$ quando comparados a controles. A frequiência de dicêntricos e anéis foi 6$27 \%$ maior (com 1 e 2 Gy) em linfócitos XP e $37 \%$ maior (com 2 Gy) em linfócitos FA do que em controles, enquanto que as deleções cromossômicas foram mais freqüentes em linfócitos XP irradiados ( $30 \%$ com 1 Gy e $72 \%$ com 2 Gy) do que em controles e 28-102\% mais freqüentes em linfócitos FA. Em linfócitos irradiados na fase $\mathrm{G}_{2}$ a freqüência total de $\mathrm{CA}$ foi $24-55 \%$ mais elevada em linfócitos XP do que em controles. Na maior parte dos casos as freqüências de translocações foram maiores do que as frequiências de dicêntricos (21/19).

\section{REFERENCES}

Arlett, C.F. and Harcourt, S.A. (1980). Survey of radiosensitivity in a variety of human cell strains. Cancer Res. 40: 926-932.

Bender, M.A. and Gooch, P.C. (1966). Somatic chromosome aberrations induced by human whole body irradiation: The "Recuplex" criticality accident. Radiat. Res. 29: 568-582.

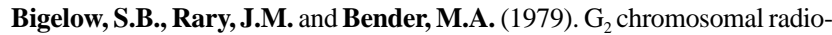
sensitivity in Fanconi's anemia. Mutat. Res. 63: 189-199.

Boei, J.J.W.A., Balajee, A.S., Boer, P. de, Rens, W., Aten, J.A., Mullenders, L.H.F. and Natarajan, A.T. (1994). Construction of mouse chromosome-specific DNA libraries and their use for the detection of X-ray induced aberrations. Int. J. Rad. Biol. 65: 583-590.

Cleaver, J.E. and Kraemer, K.H. (1989). Xeroderma pigmentosum. In: The Metabolic Basis of Inherited Disease (Scriver, C.R., Beaudet, A.L., Sly, W.S. and Valle, D., eds.). McGraw Hill, New York, pp. 29492971.

Darroudi, F., Vyas, R.C., Vermeulen, S. and Natarajan, A.T. (1995). G2 radiosensitivity of cells derived from cancer prone individuals. Mutat. Res. 328: 83-90.

Evans, H.J. (1962). Chromosome aberrations induced by ionising radiations. Int. Rev. Cytol. 13: 221-321.

Evans, H.J., Adams, A.C., Clarkson, J.M. and German, J. (1978). Chromosome aberrations and unscheduled DNA synthesis in X- and UVirradiated lymphocytes from a boy with Blooms syndrome and a man with Xeroderma pigmentosum. Cytogenet. Cell. Genet. 20: 124-140.

Finnon, P., Lloyd, D.C. and Edwards, A.A. (1995). Fluorescence in situ hybridization detection of chromosomal aberrations in human lymphocytes; applicability to biological dosimetry. Int. J. Radiat. Biol. 68: 429-435.

Kraemer, K.H. and Slor, H. (1985). Xeroderma pigmentosum. Clin. Dermatol. 3: 33-69.

Lucas, J.N., Awa, A., Straume, T., Poggensee, M., Kodama, Y., Nakano, M., Ohtaki, K., Weier, H.-U., Pinkel, D., Gray, J.W. and Littlefield, G. (1992). Rapid translocation frequency analysis in human decades after exposure to ionising radiation. Int. J. Radiat. Biol. 62: 53-63.

Mendelsohn, M.L., Mayhall, B.H., Bogart, E., Moore II, D.H. and Perry, B.H. (1973). DNA content of the various radiation induced chromosomal rearrangements in relation to the dose and sample time. Science 179: 1126-1129.

Nakano, M., Nakashima, E., Pawel, D.J., Kodama, Y. and Awa, A. (1993). Frequency of reciprocal translocations and dicentrics induced in human blood lymphocytes by X-irradiation as determined by fluorescence in situ hybridization. Int. J. Radiat. Biol. 64: 565-569.

Natarajan, A.T. (1984). Origin and significance of chromosomal alterations. In: Mutations in Man (Obe, G., ed.). Springer-Verlag, Berlin, Heidelberg, pp. 156-176.

Natarajan, A.T., Vossen, J.M.J.J. and van Weel-Sipman, M.H. (1989). Aplastic anemia and Fanconi anemia:Response of lymphocytes to X-rays and mitomycin C. In: Fanconi Anemia. Clinical, Cytogenetic and Experimental Aspects (Schroeder-Kurth, T.M., Auerbach, A.D. and Obe, G., eds.). Springer Verlag, Berlin, Heidelberg, pp. 100-104.

Natarajan, A.T., Vyas, R.C., Wiegant, J. and Curado, M.P. (1991). A cytogenetic follow-up study of the victims of a radiation accident in Goiânia 
(Brazil). Mutat. Res. 247: 103-111.

Natarajan, A.T., Vyas, R.C., Darroudi, F. and Vermeulen, S. (1992). Frequencies of X-ray induced chromosome translocations in human peripheral lymphocytes as detected by in situ hybridization using chromosome specific DNA libraries. Int. J. Radiat. Biol. 61: 199-203.

Natarajan, A.T., Balajee, A.S., Boei, J.J.W.A., Chatterjee, S., Darroudi, F., Grigorova, M., Noditi, M., Oh, H.J., Slijepcevic, P. and Vermeulen, S. (1994). Recent developments in the assessment of chromosomal damage. Int. J. Radiat. Biol. 66: 615-623.

Natarajan, A.T., Balajee, A.S., Boei, J.J.W.A., Darroudi, F., Dominguez, I., Hande, M.P., Meijers, M., Slijepcevic, P., Vermeulen, S. and Xiao, Y. (1996). Mechanisms of induction of chromosomal aberrations and their detection by fluorescence in situ hybridization. Mutat. Res. 372: 247-258.

Parshad, R., Sanford, K.K. and Jones, G.M. (1983). Chromatid damage after G2 phase X-irradiation of cells from cancer-prone individuals implicates deficiency in DNA repair. Proc. Natl. Acad. Sci. USA 80: 5612-5616.

Perry, P. and Wolff, S. (1974). New Giemsa method for differential staining of sister chromatids. Nature 251: 156-158.

Sasaki, M.S. (1978). Falconi's anemia. A condition possibly associated with defective DNA repair. In: Repair Mechanisms (Hanawalt, P.C., Friedberg, E.C. and Fox, C.F., eds.). Academic Press, New York, pp. 675-684.

Sasaki, M.S. and Miyata, H. (1968). Biological dosimetry in atom bomb survivors. Nature 220: 1189-1193.

Sasaki, M.S. and Tonomura, A. (1973). A high susceptibility of Fanconi anemia to chromosome breakage by DNA cross-linking agents. Can- cer Res. 33: 1829-1836.

Schmid, E., Zitzelsberger, H., Braselmann, H., Gray, J.W. and Bauchinger, M. (1992). Radiation induced chromosome aberrations analysed by fluorescence in situ hybridization with a triple combination of composite whole chromosome specific DNA probes. Int. J. Radiat. Biol. 62: 673-678.

Schroeder, T.M., Anschutz, F. and Knopp, A. (1964). Spontane Chromosomenaberrationen bei familiarer Panmuelopathie. Hum. Genet. 1: 194196.

Schroeder-kurth, T.M., Auerbach, A.D. and Obe, G. (1989). Fanconi Anemia: Clinical, Cytogenetic and Experimental Aspects. Springer-Verlag, Berlin.

Straume, T. and Lucas, J.N. (1993). A comparison of the yields of translocations and dicentrics measured using fluorescence in situ hybridization. Int. J. Radiat. Biol. 64: 185-187.

Taylor, A.M.R. (1978). Unrepaired DNA strand breaks in irradiated ataxia telangiactasia lymphocytes suggested from cytogenetic observations. Mutat. Res. 50: 407-418.

Vyas, R.C., Darroudi, F. and Natarajan, A.T. (1991). Radiation induced chromosome breakage and rejoining in interphase-metaphase chromosomes of human lymphocytes. Mutat. Res. 249: 29-35.

Weier, H.-U., Lucas, J.N., Poggensee, M., Segraves, R., Pinkel, D. and Gray, J.W. (1991). Two colour hybridization with high complexity chromosome specific probes and a degenerate alpha satellite probe DNA allows unambiguous discrimination between symmetrical and asymmetrical translocations. Chromosoma 100: 371-376.

(Received January 18, 2000) 
